\title{
Quality of Corner Joints of Beech Chairs under Load
}

\section{Kvaliteta kutnog spoja bukovih stolica pri opterećenju}

\author{
Original scientific paper • Izvorni znanstveni rad \\ Received-prispjelo: 15. 5. 2012. \\ Accepted-prihvaćeno: 6. 9. 2012. \\ UDK: $630 * 812.7 ; 630 * 824.1 ; 674.031 .632 .22$ \\ doi:10.5552/drind.2012.1220
}

\begin{abstract}
This paper presents quality criteria for corner joints of beech chairs by comparison of break moments during static and dynamic testing of the most frequently used type of construction joints: - round mortise and tenon. Laboratory joint testing using discursive construction methods showed a statistically supported value of the achieved results. The purpose of this paper is to investigate the possibility of shortening the testing procedure of final products and evaluate the quality of final products by segment testing of components in the design phase.

The results showed that there is a significant dependence between the Md/Ms coefficient and the number of testing cycles. This opens the possibility of a new, different approach to testing the strength of constructions, using methods for testing assemblies instead of entire final products in accordance with the applicable standard working methods.
\end{abstract}

Key words: wood constructions, sitting furniture, chair joints, strength of glued beechwood joints, round mortise and tenon

SAŽETAK • U ovom su radu izneseni kriteriji kvalitete kutnog spoja bukovih stolica usporedbom momenata lomova tijekom statičkoga i dinamičkog ispitivanja najčešće upotrebljavane vrste konstrukcijskog spoja zaobljenim čepom i podužnom rupom. Laboratorijsko ispitivanje spoja uporabom diskurzivnih konstrukcijskih metoda pokazalo je statistički podržanu vrijednost postignutih rezultata. Svrha ovog rada bila je ispitati mogućnost skraćenja postupka ispitivanja gotovih proizvoda te vrednovanje kvalitete gotovih proizvoda uz pomoć segmentnog ispitivanja sastava u fazi projektiranja.

Rezultati su pokazali da postoji signifikantna ovisnost koeficijenta Md/Ms i broja ciklusa provedenog testiranja. Ta činjenica omogućuje drugačiji, nov pristup ispitivanju izdržljivosti konstrukcija primjenom metoda ispitivanja na sklopovima umjesto na cijelim gotovim proizvodima prema važećim standardiziranim radnim metodama.

Ključne riječi: drvne konstrukcije, namještaj za sjedenje, spojevi stolica, čvrstoća slijepljenih bukovih spojeva, zaobljeni čep i podužna rupa

\section{INTRODUCTION}

1. UVOD

Research in the field of sitting furniture durability was carried out by testing actual products subjected to dynamic loads, as prescribed by the valid standards. On 48 different chair models (Jeršić et al. 1978), the joint between the rear legs and side frame was determi- ned as a critical place. In the research (Dzigielewski et al. 1983), the influence of the frame position on the achieved number of cycles subjected to a static load of 40, 60 and $80 \%$ was tested. In doing so, the authors mainly investigated the factors affecting construction strength. Due to the high cost of the experiment, the parts exposed to the heaviest loads were investigated,

\footnotetext{
${ }^{1}$ The authors are assistant professor and associate professors at Wood Technology Department, Faculty of Forestry, University of Zagreb, Croatia; ${ }^{2}$ Author is professor at University of Life Sciences in Poznan, Faculty of Wood technology, Department of Furniture Design, Poznan, Poland. ${ }^{1}$ Autori su docent i izvanredni profesori na Šumarskom fakultetu Sveučilišta u Zagrebu, Hrvatska ${ }^{2}$ Autor je redoviti profesor fakulteta Drvne tehnologije Odjela oblikovanja namještaja Sveučilišta u Poznanju, Poljska.
} 
namely the rear legs assembly and chair frame. The investigations (Eckelman, 1997; Eckelman, 1989; Tkalec and Prekrat, 1997), were carried out under real conditions. Although computer modelling methods for determination of the quality of chairs or critical joints is not new (Eckelman and Fergus, 1976), this research method has been frequent applied in recent years, (Smardzewski and Papuga, 2004; Warmbier, 1999). There are a large number of papers investigating construction quality; however, only a few deal with the dependence between static and dynamic testing of construction strength.

This paper deals with wooden chairs as the most numerous type of construction in final production, and which are especially significant in terms of their production value and share of lumber and construction elements.

Evaluation and marketing of chairs on the domestic and global markets depends primarily on their quality. One of the quality factors is durability of the glued construction under static and dynamic load during use, as specified by the Croatian sitting furniture standard HRN.D.E2.201.According to this standard, three samples of final products must be taken from regular serial production. The high costs incurred in establishing negative results could be avoided through faster and simpler quality testing. Furthermore, the use of new unconventional design solutions and new materials has become quite common, thereby increasing the need for using discursive methods in furniture construction testing.

The aim of this paper is to determine the possibilities of shortening the quality testing procedure for chairs defined by the existing standards and predicting the degree of construction durability in the design phase. The assumption is that this aim could be achieved by determining the interdependence between results of static and dynamic testing of samples of chair'corner joints.

\section{MATERIAL AND METHODS 2. MATERIJAL I METODE}

Construction durability testing was carried out on 72 identical chair samples. Samples were grouped into seven classes defined by the effect of force moment of (38.43 Nm, 47.7 Nm. 57, $69 \mathrm{Nm}, 68.94$ Nm, $76.5 \mathrm{Nm}$, $87.57 \mathrm{Nm}$ and $96.84 \mathrm{Nm})$.

Test samples were chosen in line with previous studies of sitting furniture and their assemblies, and were determined by establishing the product critical element (Eckelman and Hincz, 1977; Smardzewski, 1998; Smadzewski and Papuga, 2004; Tkalec, 1985; Wilczynski and Warmbier, 2003), made up of the joint between the rear legs and chair frame, as shown in Figure 1 .

Polyvinyl acetate glue Wegocoll HTF (Ehrengruber No. 117461 series 0243B 9K038) was used for experimental gluing of test samples. The glue and wood species (beech) represent constant parameters during the study. Due to the specific characteristics of wood as a material, the quality criteria of material and elements (Prekrat at al., 1998) comprising the joint were checked prior to gluing. These characteristics are presented in Tables 1 and 2.

Sample dimensions were adapted to the most frequently produced chairs in accordance with previous studies dealing with similar issues in order to obtain comparable results.

Any corner joint assembly consists of three constituents: legs, side and rear chair frame. Dried con-

Table 1 Physical and chemical characteristics of glue and wood

Tablica 1. Fizikalno-kemijska svojstva ljepila i drva

\begin{tabular}{|c|c|c|}
\hline \multicolumn{2}{|c|}{ Quality criteria - Kriterij kvalitete } & \\
\hline \multirow{4}{*}{$\begin{array}{l}\text { Material technical data } \\
\text { Tehnicki podaci o materijalu }\end{array}$} & Wood species / vrsta drva & $\mathrm{BE}$ \\
\hline & Growth ring width, $\mathrm{mm} /$ širina goda, $\mathrm{mm}$ & 2.5 \\
\hline & Density, $\mathrm{kg} / \mathrm{m}^{3} /$ gustoća, $\mathrm{kg} / \mathrm{m}^{3}$ & 694 \\
\hline & Wood moisture content, \% / sadržaj vode u drvu, \% & 10.42 \\
\hline \multirow{6}{*}{$\begin{array}{l}\text { Glue technical data } \\
\text { Tehnički podaci o ljepilu }\end{array}$} & Type of glue / vrsta ljepila & PVA \\
\hline & Percentage of dry matter, g / postotak suhe tvari, $g$ & 57.89 \\
\hline & Layer quantity, $\mathrm{g} / \mathrm{m}^{2} /$ količina nanosa, $\mathrm{g} / \mathrm{m}^{2}$ & 280 \\
\hline & Viscosity, cP / viskoznost, $c P$ & 14000 \\
\hline & Bonding strength, $\mathrm{N} / \mathrm{cm}^{2} /$ čvrstoća lijepljenja, $N / \mathrm{cm}^{2}$ & 9.95 \\
\hline & Drying period - until breaking, days / vrijeme sušenja (do kidanja), dana & 8 \\
\hline
\end{tabular}

Table 2 Features of chair assembly

Tablica 2. Svojstva sklopa stolice

\begin{tabular}{|l|l|c|}
\hline Quality criteria - Kriterij kvalitete & \\
\hline Dimensioning / Dimenzioniranje & Frame dimensions, $\mathrm{mm} /$ dimenzije okvirnice, $\mathrm{mm}$ & $50 \times 20$ \\
\cline { 2 - 3 } & Mortise length and width, mm / dužina i širina čepa, $\mathrm{mm}$ & $40 \times 20$ \\
\cline { 2 - 3 } & Mortise thickness, $\mathrm{mm} /$ debljina čepa, $\mathrm{mm}$ & 10 \\
\cline { 2 - 3 } & Gluing surface, $\mathrm{cm}^{2} /$ povřsina lijepljenja, $\mathrm{cm}^{2}$ & 16.45 \\
\cline { 2 - 3 } & Seat, $\mathrm{mm} /$ dosjed, $\mathrm{mm}$ & -0.25 \\
\cline { 2 - 3 } & Pressing extent, $\mathrm{mm} /$ natisnutost, $\mathrm{mm}$ & 0.49 \\
\hline
\end{tabular}



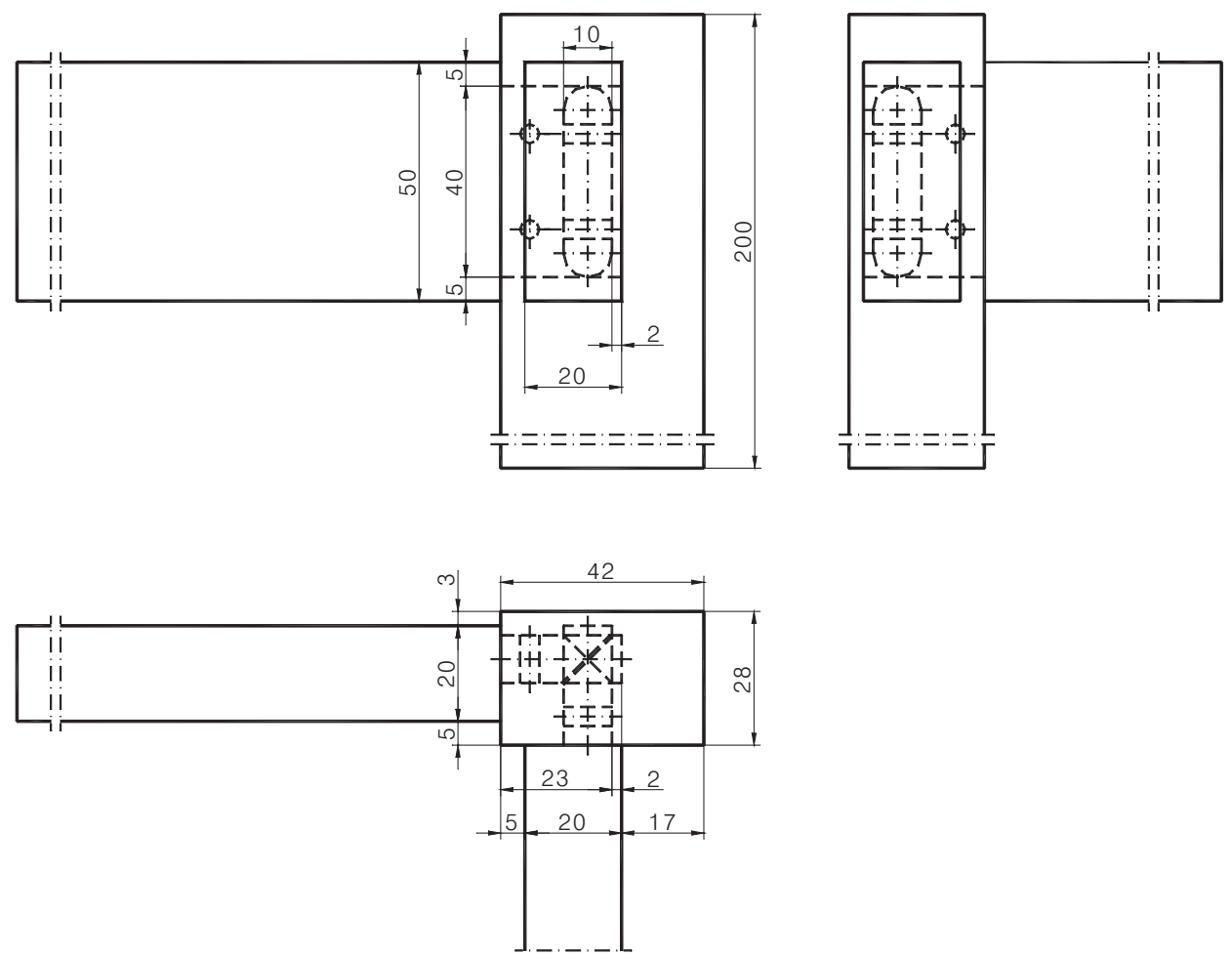

Figure 1. Round-head mortise diagonally shortened in tenons with lengthways hole Slika 1. Zaobljeni čep koso prikraćen u podužno glodanim rupama

struction elements were sawn from beech, and then planed to the final dimensions using a four-sided plane. Cross-cut dimensions of chair legs were $42 \times 28 \mathrm{~mm}$, and the dimensions of the chair frame were $50 \times 20$ $\mathrm{mm}$. Lengthways holes were made on the leg elements, and round-head mortises on the frames. The elements were glued into a system as shown in Figure 1.

Upon applying the glue on both mortise and tenon adhesion surfaces, the samples were tightened by a force of $3900 \mathrm{~N}$ for four minutes in accordance with the manufacturer's recommendation and then air conditioned at a temperature of $19.2{ }^{\circ} \mathrm{C}$ and relative humidity of $52.2 \%$. The average moisture content of samples was controlled using a calibrated electro-resistant moisture metre, and ranged from 9.56 and $11.65 \%$.

Testing of dynamic strength is carried out on constructions subjected to varying dynamic loads, which is the reason why such constructions are considerably less

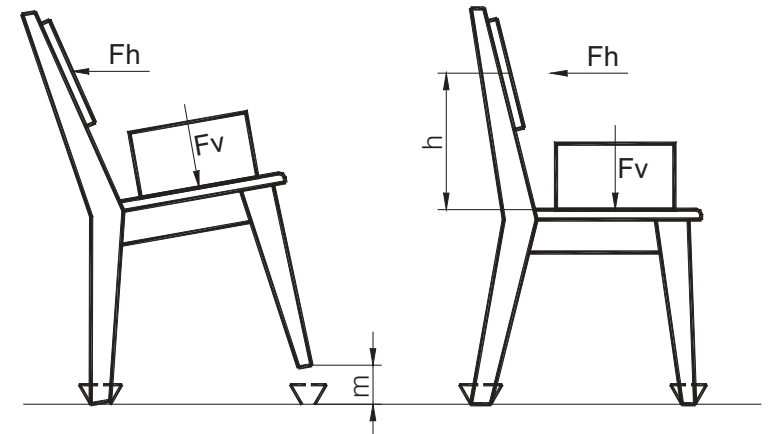

Figure 2. Scheme of chair testing according to standard Slika 2. Prikaz ispitivanja stolica prema normi

strong then those subjected to a uniform load. In Croatia the procedure for testing sitting furniture (stools, chairs and semi-armchairs) is standardised by the standard HRN.D.E2.201. which is quite similar as EN 1728 and
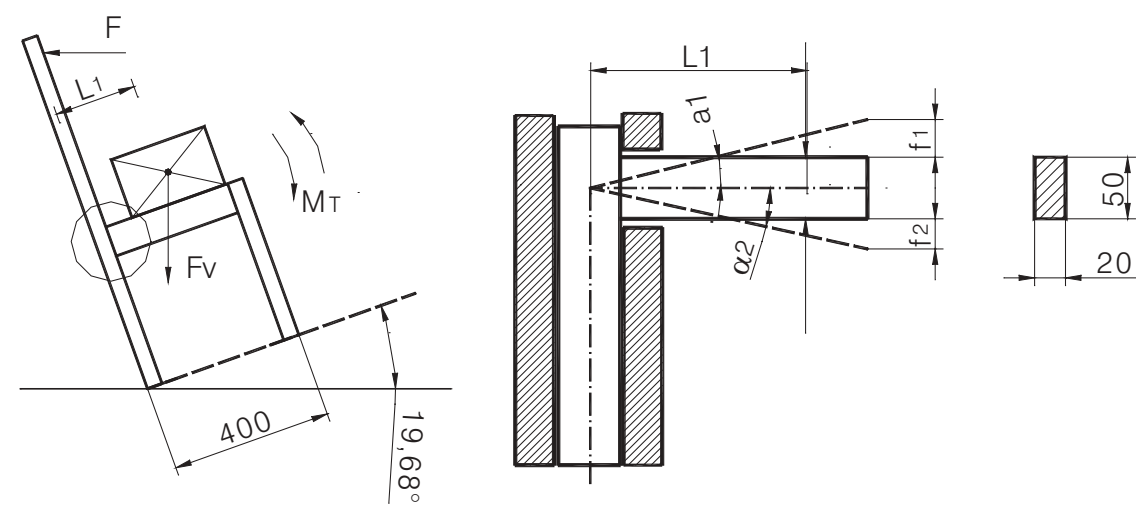

Figure 3. Scheme of dynamic testing samples derived from chair leg assembly

Slika 3. Prikaz uzorka za dinamičko ispitivanje izvedenoga prema modelu nožišta stolice 


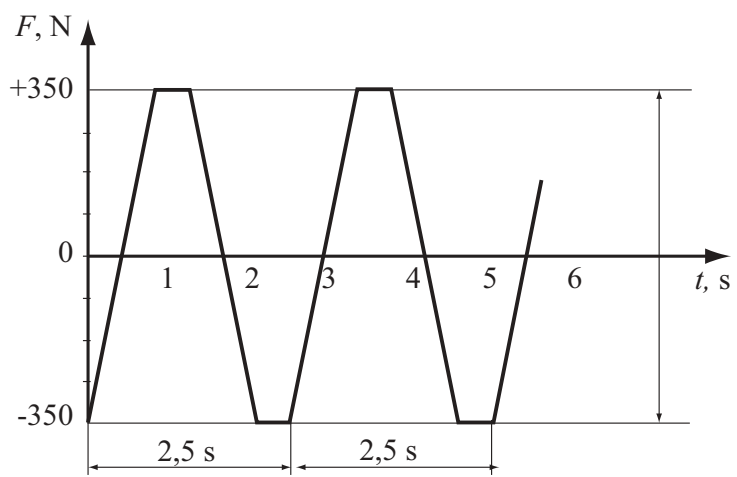

Figure 4 Regime of alternating load during dynamic strength testing

Slika 4. Režim djelovanja naizmjenične sile pri ispitivanju dinamičke čvrstoće

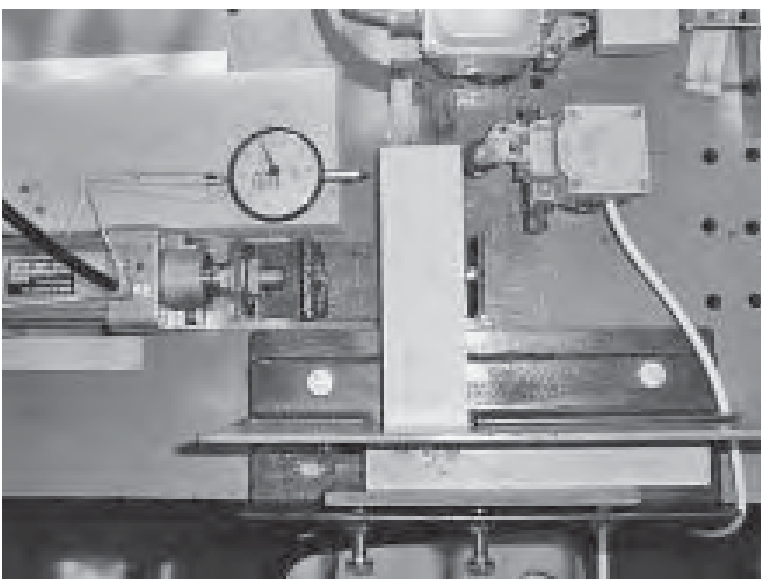

Figure 5 Device for dynamic strength testing

Slika 5. Uređaj za ispitivanje dinamičke čvrstoće

EN 12500. The standard is applied for determining the durability of chairs, and for determining the durability of semi-armchairs. Testing of chair durability subjected to dynamic loads is carried out as shown in Figure 2. Testing of joints is adapted to conditions stated in the above mentioned standards as shown in Figure 3.

The effect of alternating load on the horizontal frame of the chair seat, i.e. on the arm of the presented model is shown in Figure 4. According to this regime, these chair assemblies are subjected to an alternating load every 2.5 seconds.

For the purpose of dynamic strength testing, a pneumatic device was produced with the appropriate instruments for adjusting force and number of impulses per unit of time (Figure 5).

Testing was carried out at seven levels of operating moments ranked accordingly. All seven groups subjected to testing of specific force moments defined in Table 4. Due to the effect of the pulling strength, the occurring deformation or deviation was designated as $\mathrm{f}_{1}$ and the deformation caused by pressure force or deviation was designated as $f_{2}$ (Figure 3 ).

The break moment is obtained by multiplying break force, arm length and a cosine angle of $19.68^{\circ}$. The break moment results are expressed in Nm. The expression for calculating the break moment is as follows:

$$
M_{s}=F_{s} \cdot l \cdot \cos \alpha
$$

\section{RESULTS}

\section{REZULTATI}

In order to apply the Md/Ms coefficient, a comparison was made of the results of static testing of the same samples used in (Prekrat at al. 2004). Table 3 shows the results of static break moment testing stated in the above paper for the samples corresponding to those used in this study.

As in Prekrat at al. (2004), where the break moment distribution was tested, in this paper testing was also carried out of the normality of distribution of the achieved number of cycles for all seven groups subjected to testing of specific force moments defined in Table 4.

The Kolmogorov-Smirnov test showed that the distribution for the analysed joint was not normally distributed $(p<0.05)$. The type of error I of $5 \%$ was considered statistically significant.

Table 3 Descriptive statistics of static break moment data (Nm)

Table 3. Deskriptivna statistika za podatke statičkog momenta loma $(\mathrm{Nm})$

\begin{tabular}{|l|c|}
\hline Number of samples / Broj uzoraka & 29 \\
\hline Mean value / Srednja vrijednost & 1543.6 \\
\hline Median / Medijan & 1543.8 \\
\hline Sum / Zbroj & 44766.0 \\
\hline Minimum / Minimum & 1361.2 \\
\hline Maximum / Maksimum & 1684.9 \\
\hline Variance / Varijanca & 8250.2 \\
\hline Standard deviation / Standardna devijacija & 90.83 \\
\hline Standard error / Standardna greška & 16.86679 \\
\hline
\end{tabular}

Table 4 Descriptive statistics of data for all dynamic break moments (Nm)

Tablica 4. Deskriptivna statistika za podatke svih dinamičkih momenata loma (Nm)

\begin{tabular}{|c|c|c|c|c|c|c|c|c|}
\hline $\begin{array}{c}\text { Moment } \\
\text { Moment } \\
\text { Nm }\end{array}$ & $\begin{array}{c}\text { Mean } \\
\text { value } \\
\text { Srednja } \\
\text { vrijednost }\end{array}$ & $\begin{array}{c}\text { Median } \\
\text { Medijan }\end{array}$ & $\begin{array}{c}\text { Sum } \\
\text { Zbroj }\end{array}$ & $\begin{array}{c}\text { Mini- } \\
\text { mum } \\
\text { Minimum }\end{array}$ & $\begin{array}{c}\text { Maximum } \\
\text { Maksimum }\end{array}$ & $\begin{array}{c}\text { Variance } \\
\text { Varijanca }\end{array}$ & $\begin{array}{c}\text { Standard } \\
\text { deviation } \\
\text { Standardna } \\
\text { devijacija }\end{array}$ & $\begin{array}{c}\text { Standard } \\
\text { error } \\
\text { Standardna } \\
\text { greška }\end{array}$ \\
\hline 96.57 & 48.44 & 44.0 & 436 & 32 & 74 & 208.3 & 14.43 & 4.81 \\
\hline 87.57 & 68.12 & 49.0 & 1158 & 18 & 205 & 2106.1 & 45.89 & 11.13 \\
\hline 76.50 & 185.30 & 165.0 & 2038 & 59 & 314 & 11091.0 & 105.31 & 31.75 \\
\hline 68.94 & 259.40 & 228.5 & 2594 & 129 & 556 & 16632.0 & 128.96 & 40.78 \\
\hline 57.69 & 425.00 & 500.0 & 5525 & 227 & 644 & 22676.0 & 150.59 & 41.77 \\
\hline 47.40 & 900.50 & 719.5 & 9005 & 360 & 2091 & 266516.0 & 516.25 & 163.25 \\
\hline 38.43 & 7406.20 & 5902.0 & 81468 & 1617 & 13944 & 13228553.0 & 3637.11 & 1096.63 \\
\hline
\end{tabular}




\section{DISCUSSION}

\section{DISKUSIJA}

Many authors have investigated the influence of construction factors of different corner joints used in chair production, and a considerable dependence between gluing strength and the adhesion surface has been established (Wang and Yuang 1994). There are also significant studies that determine the position of corner joints in testing the effects of force (Warmbier 1999). The greatest problem in comparing results is incomplete data on samples or the material they are made from. Joint strength depends on specific sample mass (Wang and Yuang, 1994), and variation was reported in large data dispersion of volume mass of beech wood (Fagus Sylvatica L.) from different stands (Tkalec, 1985). (Tkalec, 1985) reported the influence of seat and pressing extent of mortise not stated in the papers of other authors. Furthermore, the influence of technological factors is also significant for comparing results, as seen in (Biniek and Smardzewski 1987), where the impact of moisture on joint strength was examined. In the study (Dziegielewski, 1991), dependence between the manner of glue application on the adhesion surfaces and joint strength is outlined as a highly significant technological factor. Furthermore, it is necessary to give a detailed definition of the material and design in standardising the forces of static testing that correspond to a specific number of dynamic testing cycles.

In order to determine the interdependence between static and dynamic testing methods, a previous study (Prekrat at al., 2004) was used to calculate the coefficient equal to the quotient of dynamic and static moment of force. Due to insufficiently defined material parameters, there are difficulties in comparing the results with the results listed in the literature. For this reason, the comparison was made on the basis of the said research, whose samples were made under the same conditions and from the same material. The coefficient was calculated for each level of moment of force. The dependence between the results of static and dynamic testing methods was determined by the correlation between the $\mathrm{Md} / \mathrm{Ms}$ coefficient and the number
Table 5. Moments data and coefficients for test samples Tablica 5. Podaci momenata i koeficijenti za testirane uzorke

\begin{tabular}{|c|c|c|c|}
\hline $\boldsymbol{M d}$ & $\boldsymbol{M s}$ & $\begin{array}{c}\text { Number of cycles } \\
\text { Broj ciklusa }\end{array}$ & $\begin{array}{c}\text { Md/Ms coefficient } \\
\text { Koeficijent }\end{array}$ \\
\cline { 1 - 2 } $\mathrm{Nm}$ & $\mathrm{Nm}$ & & \\
\hline 38.43 & 154.36 & 7406.18 & 0.248963 \\
\hline 47.40 & 154.36 & 900.50 & 0.307074 \\
\hline 57.69 & 154.36 & 425.00 & 0.373737 \\
\hline 68.94 & 154.36 & 259.40 & 0.446618 \\
\hline 76.50 & 154.36 & 185.27 & 0.495595 \\
\hline 87.57 & 154.36 & 68.12 & 0.567310 \\
\hline 96.57 & 154.36 & 48.44 & 0.625615 \\
\hline
\end{tabular}

of achieved cycles for each of the seven different values of moment of force. Table 5 presents the moment values to which the sample was subjected during testing, static and dynamic moments of force, number of achieved cycles until breaking and the calculated coefficient. The correlation is shown in Figure 6.

The high correlation coefficient $\left(R^{2}=0.9167\right)$ indicates a high dependence between the static and dynamic testing of samples. This dependence indicates the possibility of shortening the long dynamic testing prescribed under the current standards. Figure 6 shows the dependence curve of coefficient $k_{\mathrm{ds}}$ and the number of achieved cycles until breakage.

\section{CONCLUSIONS}

5. ZAKLJUČAK

Based on the corner joints tested in this paper, the following can be concluded:

- a significant correlation was established between the results of static and dynamic testing of joints, using the expressed $\mathrm{Md} / \mathrm{Ms}$ coefficient and the number of cycles of joints dynamically tested in this paper and in comparison with the results of previous studies;

- the results are applicable to further research in innovating design solutions and in practical application in testing chair quality;

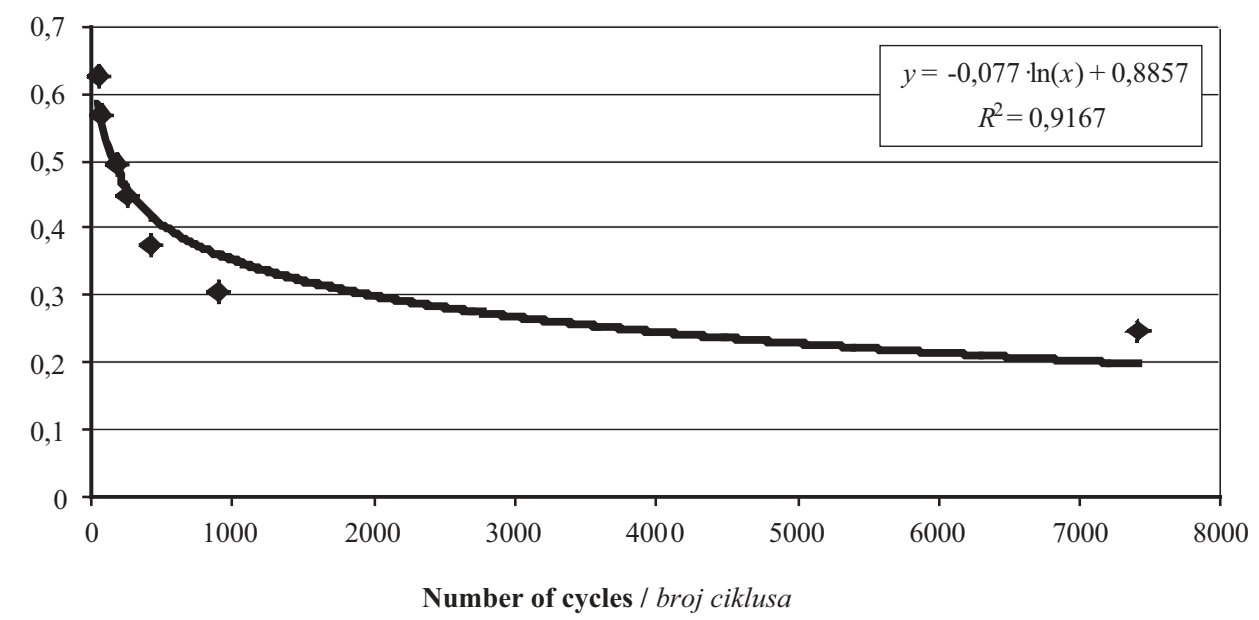

Figure 6 Dependence of the Md/Ms coefficent and cycle number for sample

Slika 6. Ovisnost koeficijenta Md/Ms o broju ciklusa za skupinu uzoraka 
- there are other possibilities in the approach to checking quality through the partial testing of key assemblies for the durability of sitting furniture;

- this procedure can considerably contribute to successful planning and manufacturing of industrial products.

\section{REFERENCES}

6. LITERATURA

1. Biniek, P.; Smardzewski, J., 1987: Effect of simultaneous changes in several factors on the strength of fork-tenoned joints, Przemysl -Drzewny, 38 (11): 6-8.

2. Dzigielewski, S.; Gemza, I.;Grbac, I., 1983: Istraživanje statičke i dinamičke čvrstoće stolica kao parametra njihove kvalitete, Drvna industrija 34 (1-2): 5-9.

3. Dziegielewski. S., 1991: Sposoby nanosenia klejuna powierzchine zlaczy a jakosc polaczenia. Przemysl Drzewny 7: 10-13.

4. Eckelman, C. A.; Fergus, D. A., 1976: Compute analysis of chair frames (Fortran and Basic), Research Bulletin Agricultural Experiment Station Purdue University, 237, $24 \mathrm{pp}$.

5. Eckelman, C. A.; Hincz, T.W., 1977: Strength and stiffness of dowel joints in flatwise bending, Forest Products Journal. 1: 15-17.

6. Eckelman, C. A, 1997: Withdrawal strength of dowel joints: effect of shear strength, Forest Products Journal, 29 (1): 48-52

7. Eckelman, C. A., 1989: Strength of furniture joints constructed with through bolts and dowel nuts, Forest Products Journal, 39 (11-12): 41-48.

8. Jeršić et al, 1978: Faktori kvalitete stolica, Drvna industrija, 29 (9): 227-234.

9. Prekrat, S.; Tkalec, S.; Grbac, I., 1998: Defining the criteria for technical quality of wood structures at automatic furniture construction, International design conference Design 98, Fakultet strojarstva i brodogradnje Sveučilišta u Zagrebu, Dubrovnik, 475-479.

10. Prekrat, S.; Jazbec, A.; Pervan, S., 2004: Analysis of bending moment of innovative corner joints during static testing, Wood research, 49 (1):21-32.

11. Smardzewski, J., 1998. Numerical analysis of furniture constructions, Wood Science and Technology, 32: 273286 http://dx.doi.org/10.1007/BF00702895.

12. Smardzewski, J.; Papuga, T., 2004: Stress distribution in angle joints of skeleton furniture, Electronic journal of polish agricultural universities, 7 (2004), 1.

13. Tkalec, S., 1985: Utjecaj konstrukcijskih spojeva na kvalitetu stolica, Doktorska disertacija, Šumarski fakultet Sveučilišta u Zagrebu, 1-347.

14. Tkalec, S.; Prekrat, S., 1997: Čvrstoća spojeva u konstrukcijama stolica od borovine i bukovine, Drvna industrija 48 (1): 10-16.

15. Warmbier, K. 1999: Badania drewnianych polaczen katowych plaskich o wybranych zlaczach, Praca doktorska wykonana, Instytucie Techniki Wyzszej Szkoly Pedagogicznej w Bydgoszczy.

16. Wilczynski, A.; Warmbier, K., 2003: Effect of joint dimensions on strength and stiffness of tenon joints, Folia forestalia polonica, 34, 53-66

\section{Corresponding address:}

Assist. Prof. SILVANA PREKRAT, Ph.D.

University of Zagreb, Faculty of Forestry Department of Wood technology Svetošimunska 25, 10000 Zagreb, CROATIA e-mail: prekrat@sumfak.hr 